\title{
Bio-Rational Management of Maize Weevil, Sitophilus Zeamais in Maize (Zea Mays) Seeds
}

\author{
M. M. Mahabub Alam¹, Masum Ahmad², Md. Sohanur Rahman³, Fakhar Uddin Talukder ${ }^{3}$, Md. Israfil Jahan ${ }^{1} \&$ \\ R. Hossain ${ }^{4}$ \\ ${ }^{1}$ Department of Seed Science and Technology, Bangladesh Agricultural University, Mymensingh, Bangladesh \\ ${ }^{2}$ Professor, Department of Entomology, Bangladesh Agricultural University, Mymensingh, Bangladesh \\ ${ }^{3}$ Scientific Officer, Pest Management Division, Bangladesh Jute Research Institute, Dhaka, Bangladesh \\ ${ }^{4}$ Scientific Officer, Bangladesh Institute of Nuclear Agriculture, Bangladesh \\ Correspondence: Md. Sohanur Rahman, Scientific Officer, Pest Management Division, Bangladesh Jute Research \\ Institute, Bangladesh. E-mail: sohanbau2010@gmail.com
}

Received: June 6, 2020 Accepted: July 16, 2020 Online Published: July 22, 2020

\begin{abstract}
Bangladesh is a sub-tropical and humid country. That is why, the infestation of insects during storage is very common here. The maize weevil, Sitophilus zeamais Motschulsky (Coleoptera: Curculionidae), locally known as "Katta Poka", is one of the most serious cosmopolitan pest of stored cereal grain, especially of maize (Zea mays L.), in tropical and subtropical regions including Bangladesh. Considering the issue, the study was conducted in the laboratory of Department of Entomology, Bangladesh Agricultural University (BAU) following completely randomized design (CRD) with three replications to evaluate the efficacy of four locally available botanicals and chemicals. The botanicals used were: Neem (Azadirachta indica) leaf, Datura (Datura stramonium) leaf, Nishinda (Vitex negundo L) leaf and Garlic (Allium sativum L.) tablet powders at three different doses (3, 4 and 5gm)/100g of grain seed against maize weevil. The results revealed that all test materials at $5 \mathrm{~g}$ doses exhibited higher mortality action against maize weevil while at $3 \mathrm{~g}$ doses it gave the lowest percentage efficacy. Powdered leaves of neem and datura at 4 and $5 \mathrm{gm}$ were showed statistical significant $(\mathrm{P}<0.01)$ differences while powdered leaves of nishinda at the similar rates were observed with moderately effectiveness and powdered tablet of garlic gave the lowest mortality rate within 28 days of exposure in all tested doses. These findings suggest that botanical treatments exerted better mortality of maize weevil and reduced maize seed weight loss with higher germination capacity compared to the untreated control. It was also observed that the highest mortality percentage, lowest seed weight loss and highest germination capacity in the seeds which were treated with Sevin $85 \mathrm{SP}$ at the rate of $0.25 \mathrm{~g} / 100 \mathrm{~g}$ maize seeds. Maize grains treated with botanicals, indicated that insect reproduction and development were impaired in all botanical pesticides. It is suggested that datura leaf, neem leaf powder can be used as good alternatives to chemical insecticides against $S$. zeamays due to their higher mortality, lower seed weight losses and higher germination capacity.
\end{abstract}

Keywords: neem, datura, nishinda, garlic, sevin 85 sp, mortality, seed weight, germination

\section{Introduction}

Maize (Zea mays) is under the family of Poaceae. Maize is the third most important cereal crop. It is one of the most popular crop plants grown in over 140 million hectares (Zaidi, Singh 2005) It is used as a staple human food, feed livestock and a raw material for many industrial products (Purseglove, 1975). The products include corn starch, maltodextrins, corn oil, corn syrup and products of fermentation. It is also used as bio-fuel. The importance of export and import of maize is an important issue of the world trade. The United States, China, Brazil and Mexico account for $70 \%$ of global production. India contributes $2 \%$ of world production. Maize usage varies in different countries. In the developed countries of the world like the USA, Canada, Australia, Russia, the countries of the European Union (EU) and so on, maize is used mainly to feed animal directly and as raw material for extractive fermentation industries to produce alcohol and bio-fuel. In developing countries use of maize is variable. In Latin America and Africa the main use of maize is for food while in Asia for food and animal feed. It is the basic staple food and important ingredient in the diets of people for many countries. Worldwide, approximately $21 \%$ of the total grain produced is consumed as food (Shaw, 1988; Dowswell et. al., 1996). 
The third most important cereal crop of Bangladesh is maize. In Bangladesh it is mainly used for poultry and livestock feed and also for human food in the form of various edible items. Maize production in Bangladesh is popularizing for its multifarious use for food, feed and edible oil preparation (Ahad, 2003). The cultivation of maize is increasing day by day due to its diversified use, where the total area coverage and productions were 8.04 lakh acres with a production of 22.72 lakh metric tons in 2014-2015 (BBS, 2015), 8.27 lakh acres with a production of 24.46 lakh metric tons in 2015-2016 (BBS, 2016) and 9.63 lakh acres with a production of 30.26 lakh metric tons in 2016-2017 (BBS, 2017). The maize is richer in nutrition than rice and wheat, where it contains $11 \%$ protein including higher amount of essential amino acid, tryptophan and lysine. Besides these, it contains $90 \mathrm{mg}$ carotene or vitamin A per 100g grains (Hossain et al., 2005).

In developing countries, as a result of post-harvest losses due to storage pests and other spoilage agents, production and consumption of maize often falls below demand (Udo, 2005) resulting in economic losses and threatens food security (Ivbijaro et al. 1979). Developing countries face severe problems due to unfavorable storage conditions and poor storage structures (Bekele et al. 1997). High moisture predisposes grain to attack by bacteria, fungi, insects and other microbes (Golob, 2000). Bangladesh is a sub-tropical and humid country. That is why; the infestation of insects during storage is very common here.

The maize weevil, Sitophilus zeamais Motschulsky (Coleoptera: Curculionidae), locally known as "Katta Poka", is one of the dangerous pest of stored cereal grain, especially of maize (Zea mays L.), in tropical and subtropical regions (Throne, 1994) including Bangladesh. The weevil has been stated to cause up to $80 \%$ grain damage during storage in Cameroon, where maize constitutes the most important food crop (Nukenine et al., 2002). Due to damaged grain, nutritional value, low percentage germination, reduced weight and lowered market value has been reduced (Demissie et al., 2008). To reduce S. zeamais damage cheap and effective methods are needed in food insecurity. Control of S. zeamais populations primarily depends upon constant application of synthetic insecticides, which are often the most effective treatments for the disinfestations of stored food, feedstuffs and other agricultural commodities from insect infestation. Their repeated use for decades has destroyed biological control by natural enemies and led to outbreaks of other insect species and sometimes resulted in resistant capacity (Park et al., 2003). There are also serious concerns about environmental degradation and human health. The majority of farmers in Bangladesh are poor and neither have the means nor the skills to obtain and handle pesticides appropriately. Safe and eco-friendly weevil control practice needs to be available.

Plant materials create a scope for small farmers for pest control (Talukder \& Howse, 1995). However, very few research work has been done on organic pesticides which offer same control levels as synthetics to weevils (Cosmas et al., 2012). Botanical pesticides are generally safe to human beings and environment than synthetic pesticides. That's why; it is used for millions of years without any adverse effects on ecosystem. These botanical materials can be used as an alternative to chemical pesticides. This study will provide useful information in minimizing the undesirable side effects of synthetic pesticides. The present study was, therefore, undertaken to evaluate the toxic effects of four available plant products such as neem, datura, garlic tablet and nishinda leaf powder and a chemical i.e. Sevin 85 SP in controlling maize weevil considering mortality of maize weevil, seed weight loss and germination of maize seeds.

\section{Materials and Methods}

The study was done to find out the effect of four plant products and a chemical insecticide such as neem leaf powder, datura leaf powder, nishinda leaf powder, garlic tablet powder and Sevin $85 \mathrm{SP}$ against maize weevil, Sitophilus zeamais Motschulsky in the laboratory of the Department of Seed Science and Technology, Bangladesh Agricultural University (BAU), Mymensingh, during the period from August to October 2018. This place receives an average rainfall of $1295 \mathrm{~mm} /$ annum. Temperature in the laboratory ranged from $25-31^{\circ} \mathrm{C}$ and the relative humidity also varied from $68-75 \%$ during the experimenting period. The laboratory was kept well aerated throughout the study.

\subsection{Collection and De-Infestation of Maize Seeds}

An open pollinated maize variety "Khai Bhutta" sourced from Agronomy farm, Bangladesh Agricultural University (BAU), Mymensingh) was used because it has stable yields in adverse conditions such as drought due to its heterogeneity and commonly grown by most resource poor small holder farmers (ref). Dirt from the maize was removed through winnowing as suggested by Masiiwa (2004) and the grain cleaned using a $1 \mathrm{~mm}$ sieve mesh screen so as to remain with intact kernels. Moisture content of the maize seed was maintained $11-12 \%$ following procedures described at the Manual of Seed Quality control (2006). The maize grain was graded manually and cleaned of broken kernels and debris (Fekadu et al., 2012). Before artificial infestation of maize seeds with maize weevil, the maize seeds were dried in the sun for few days. Islam et al. (2000) reported that solar heat treatment 
of grains destroys the initial insect infestation in the grains before storage. The maize seed was kept in a plastic jar in cool dry room to avoid accumulation of moisture.

\subsection{Botanical Species Tested as Biopesticides}

Three different rates of four biopesticides (3, 4 and $5 \mathrm{gm} / 100 \mathrm{~g}$ seeds) were used for the experiment, namely, Neem (Azadirachta indica - Meliaceae), Datura (Datura stramonium - Solanaceae), Garlic (Allium sativum L.- Liliaceae), Nishinda (Vitex negundo L. - Verbenaceae). Sevin $85 \mathrm{SP}$, a chemical pesticide was also used as a treatment. What was the source of the biopesticides.

\subsection{Test Insect}

The present study was conducted with major stored grain pest of maize named maize weevil, Sitophilus zeamais Motschulsky under Curculionidae family of Coleoptera order.

\subsection{Collection and Rearing of Insect}

Maize weevils, S. zeamais were collected from a store room of a poultry feed wholesaler at Muktagacha upazilla of Mymensingh district. The insects were brought to the laboratory of the Department of Entomology, Bangladesh Agricultural University (BAU), Mymensingh. The insects were maintained in the growth chamber at $27-30^{\circ} \mathrm{C}$ and $70-75 \% \mathrm{RH}$. The insects were reared on fresh maize seeds in rectangular jars of size $14 \times 10 \times 30 \mathrm{~cm}$. Each jar was set up with 20 pairs of adult beetles. Maize seeds were kept in an oven overnight at $30^{\circ} \mathrm{C}$ temperature to avoid pre infestation. The moisture content of maize grain was adjusted to $12-13 \%$. Then maize seeds were used as food for maize weevil. The jars were covered with a piece of cloth fastened with rubber band to prevent contamination and insect escape. After allowing free oviposition for a period of 14 days, all the adults of maize weevils were removed from each jar. Then the jars were put back into growth chamber for completing the generation of insects. The $F_{1}$ generation was used for the experiment.

\subsection{Collection and Preparation of Tested Botanical Products}

Neem, datura and nishinda leaves were collected from Bangladesh Agricultural University (BAU) premises and dried under the shed for 14 days. Then they were grinded by hand grinder in the Integrated Pest Management (IPM) Laboratory, Department of Entomology, BAU. Before grinding, leaves were dried in the oven at $70^{\circ} \mathrm{C}$ for 24 hours to make the leaves crispy which allowed them to fine grinding. Then the grinded materials were sieved with $1 \mathrm{~mm}$ sieve to fine powders of botanical materials.

\subsubsection{Garlic Tablet}

The garlic tablets were prepared at the Plant Pathology laboratory on the Department of Plant Pathology, BAU, Mymensingh. For the preparation of garlic tablets, at first garlic was collected from the K.R. market BAU campus, Mymensingh. After that the garlic cloves were separated from each garlic bulb and washed in the clean water. Then these cloves were blended in the blender machine. From the blended materials, tablets were prepared and kept in open air for drying for three days. After that the tablets were preserved in an air tied bottle.
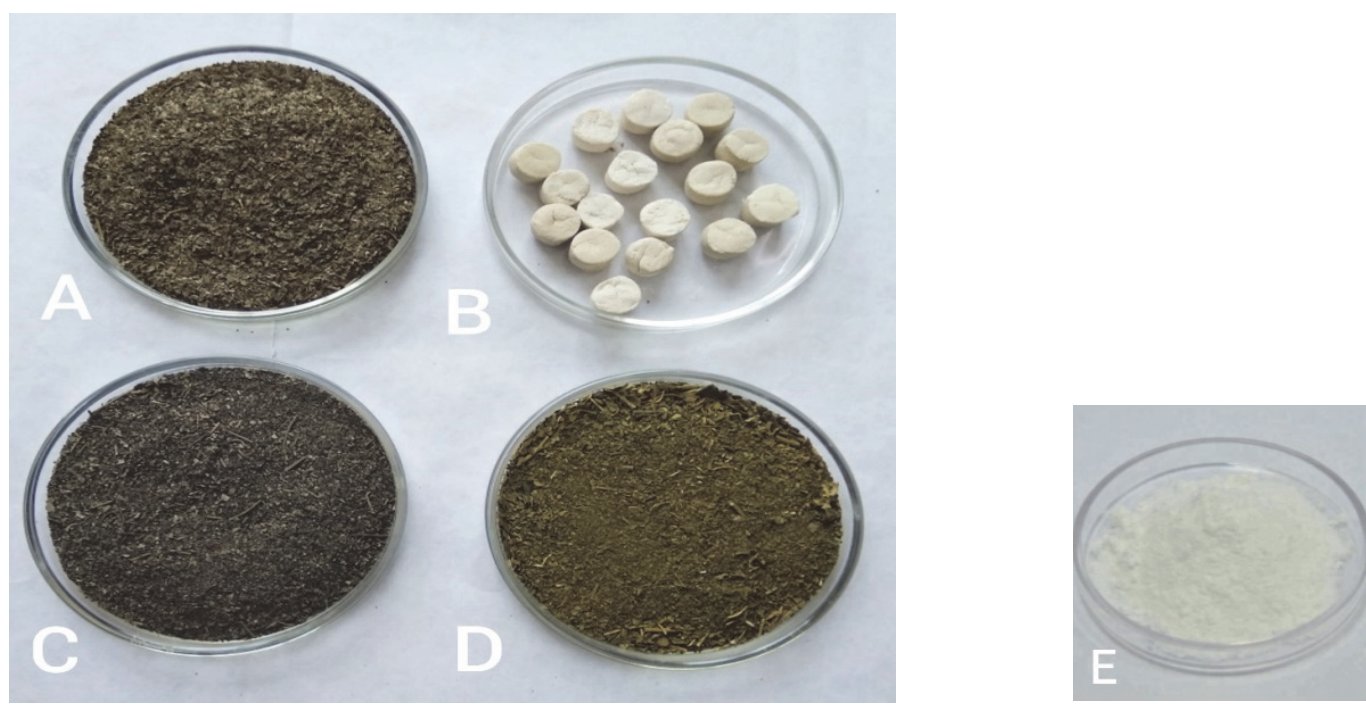

Plate 1. Prepared Botanical Materials (A) Neem leaf powder, (B) Garlic tablet, (C) Nishinda leaf powder, (D) Datura leaf powder, (E) Garlic tablet in broken form 


\subsection{Test Chemical Material (Sevin 85SP)}

Sevin $85 \mathrm{SP}$ is a contact and slightly systemic organo carbamate insecticide in powder formulation. It was purchased from a local insecticide store situated at Notun Bazar of Mymensingh Sadar packed in a 50g pack manufactured by Bayer Crop Science, Bangladesh Limited.

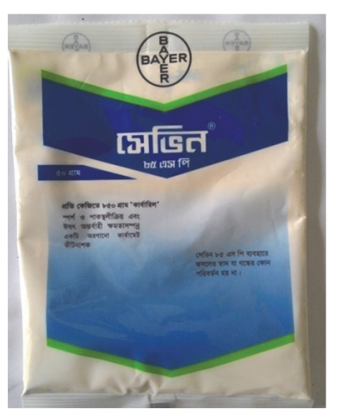

Plate 2. Sevin 85 SP

\subsection{Tested Rates of Botanical Products and Chemical}

In the experiment prepared neem, datura, nishinda leaf powder and garlic tablet powder were used at three different rates $(\mathrm{w} / \mathrm{w})$ as 3, 4 and $5 \mathrm{~g}$ per $100 \mathrm{~g}$ maize seeds ), while in control treatment there was no any botanicals added and in the standard check Sevin $85 \mathrm{SP}$ dust was added in $0.25 \mathrm{~g} / 100 \mathrm{~g}$ of maize seed.

\subsection{Treatment Application}

Twenty pairs of $S$. zeamais were introduced into the plastic jar containing $100 \mathrm{~g}$ grain maize in 0.5 liter plastic jars at 3,4 and $5 \mathrm{~g} \%(\mathrm{w} / \mathrm{w})$. Four botanicals and Sevin $85 \mathrm{SP}$ with their recommended dosage were weighed and added to the maize grain in each jar containing $100 \mathrm{~g}$ grain maize in 0.5 liter plastic jars at 3,4 and $5 \mathrm{~g} \%(\mathrm{w} / \mathrm{w})$ and kept for 28 days and mortality rate were counted daily every 1, 7, 14, 21 and 28 days after application of treatments.

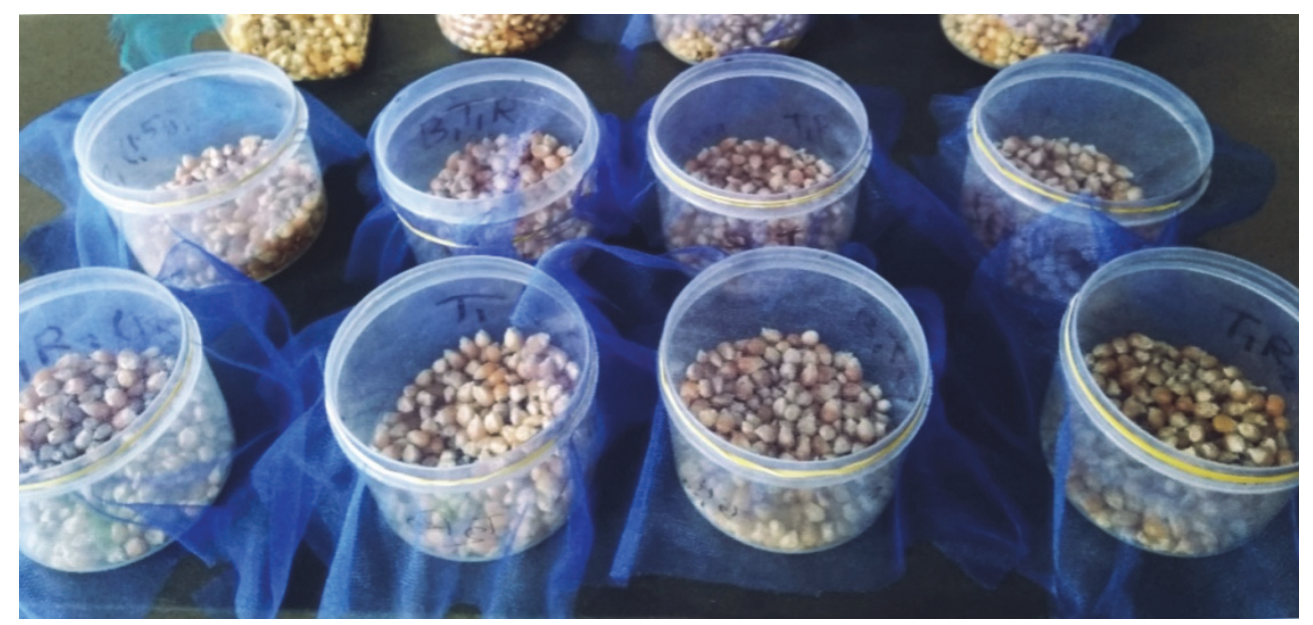

Plate 3. Experimental set up of Maize seeds with treatments

\subsection{Mortality Test of Maize Weevil}

Mortality rate determination periods selected based on an earlier report by Dobie, (1974) \& Girma et al. (2008) and calculated by the following formula: 


\section{Number of dead insects}

$\%$ Weevil mortality $=$ $\mathrm{x} 100$

Total number of insects released

\subsection{Seed Weight Loss Assessment of Maize Seeds}

Percent insect damage of maize seeds in storage was computed according to the methods described in Haines (1991) as follows:

$$
\text { Percent of weight loss }=\frac{\mathrm{UNd}-\mathrm{DNu}}{\mathrm{U}(\mathrm{Nd}+\mathrm{Nu})} \times 100
$$

Where $\mathrm{U}=$ weight of undamaged seeds, $\mathrm{D}=$ weight of insect- damaged seeds, $\mathrm{Nu}=$ number of undamaged seeds and $\mathrm{Nd}=$ number of insect- damaged seeds

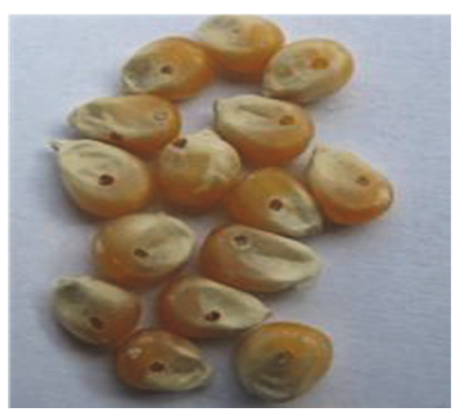

Plate 4. Infested Maize seeds with hole

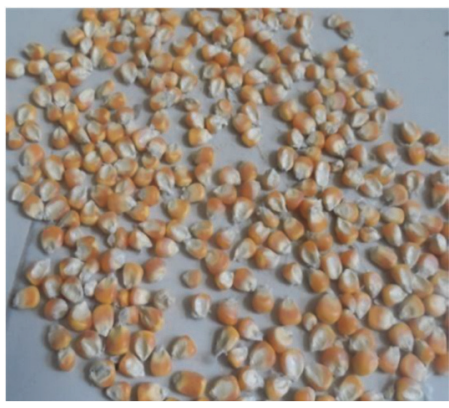

Plate 5. Healthy Maize seeds

\subsection{Seed Germination}

The percent germination was computed according to the following formula:

$$
\text { Germination }(\%)=\frac{\mathrm{NG}}{\mathrm{TG}} \times 100
$$

Where,

$\mathrm{NG}=$ Number of seeds that germinated

$\mathrm{TG}=$ Total number of test seeds.

\subsection{Statistical Analyses}

The experimental data were analysed by STATISTIX 10 software. The mean values were separated by Duncans multiple range test (DMRT) (Duncan, 1951).

\section{Results and Discussion}

The results of the effect of different botanical products such as neem leaf powder, datura leaf powder, nishinda leaf powder and garlic tablet powder and a chemical such as Sevin 85 SP were evaluated against maize weevil. The results of the experiments conducted during the study period are presented below:

\subsection{Effect of Botanicals and Chemical on Mortality of Maize Weevil}

The efficacy of different botanical products viz. neem leaf powder, datura leaf powder, nishinda leaf powder and garlic tablet powder and a chemical (Sevin $85 \mathrm{SP}$ ) were evaluated as seed protectants against maize weevil are presented in Figure 1. The rates used for neem leaf powder, datura leaf powder, nishinda leaf powder and garlic tablet powder were 3, 4 and $5 \mathrm{~g}$ per $100 \mathrm{~g}$ maize seeds and for Sevin $85 \mathrm{SP}$ was $0.25 \mathrm{~g}$ per $100 \mathrm{~g}$ maize seeds. 


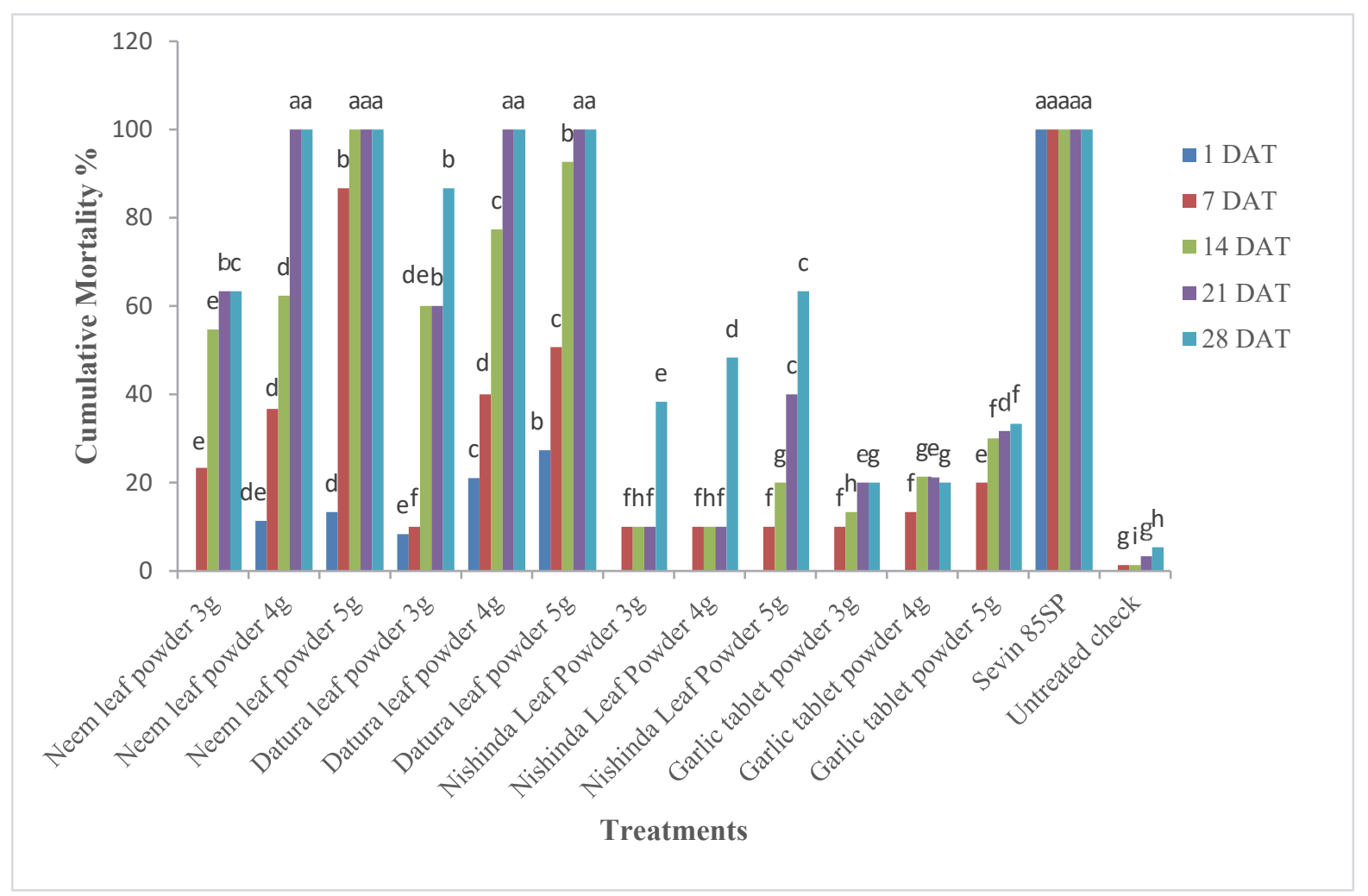

Figure 1. Effect of all treatments on mortality of maize weevil

Figure 1 represents the interaction between treatments and mortality of maize weevil at different DAT which showed significant difference. It was observed that with the progress of time the mortality percentage was increased. The effects of treatments at different rates and time of application showed significant difference on insect mortality. It was found that when Sevin $85 \mathrm{SP}$ was used at the rate of $0.25 \mathrm{~g} / 100 \mathrm{~g}$ maize seeds, exerted highest mortality (100\%) of maize weevil from 1 DAT which was significantly different from all other treatments. At 28 DAT, Sevin 85 SP showed $100 \%$ mortality which was statistically similar to Neem and Datura leaf powder at the rate of $4 \mathrm{~g}$ and $5 \mathrm{~g} / 100 \mathrm{~g}$ respectively ( Fig. 1) However, the lowest mortality of maize weevil was observed in the untreated check. On the other hand, all botanical materials showed higher mortality of maize weevil at the rate of $5 \mathrm{~g} / 100 \mathrm{~g}$ maize seeds than of $4 \mathrm{~g} / 100 \mathrm{~g}$ maize seeds while $3 \mathrm{~g} / 100 \mathrm{~g}$ maize seeds showed the lowest mortality of maize weevil. Among the botanical treatments, datura leaf powder showed the highest mortality $(100 \%)$ of maize weevil followed by neem leaf powder, nishinda leaf powder and garlic tablet powder at all rates in different time intervals. This result supports the findings of Shiberu and Negeri (2014) who stated that powdered leaves and seeds of neem at 4 and $5 \mathrm{~g}$ were showed statistical significant $(\mathrm{P}<0.01)$ differences with the other botanical materials within 28 days of exposure in all tested rates. Endersby and Morgan (1991) observed that $A$. indica derivatives are most effective as feeding deterents for nymphs or larvae of phytophagous insects. Hall (1990) observed that leaf powder of Datura have a repellent effect on olfactory and gustatory system of $S$. zeamais. Moreover, Mulungu et al. (2007) reported that the crushed dry datura leaves have been observed to have their repellent smell which can be utilized for effective control of stored maize grain pests like $S$. zeamais. Marilei et al.,(2010) also reported that $40 \mathrm{~g}$ of corn treated with $6 \mathrm{~g}$ of the extracts from leaves and seeds extracts from neem can be considered as a viable alternative for controlling the S. zeamais in stored maize. It is also supported the findings of Maribet \& Aurea (2008) who found that lower mortality of adult maize weevils from corn grains treated with Allium sativum L. within 24 days after insect introduction. Jilani and Saxena (1990) observed that neem, turmeric and sweet flag had repellent action on stored grain pests.

Nazli et al. (2008) reported that the garlic oil, in the laboratory studies, as an insect repellent against red flour beetle. They observed repellence of the beetles up to $52.25 \%$, in response to the garlic oil, obtained from Hyderabad. Rajendran and Sriranjini (2008) reported that garlic a rich source of bioactive metabolites which show antifeedant, repellent and toxic effects in a wide range of insects. 


\subsection{Effect of Botanicals and Chemical on Seed Weight Loss of Maize Seeds}

Table 1. Effect of botanical and chemical treatments on percent seed weight loss of maize

\begin{tabular}{c|cc}
\hline Treatments & Rate $/ 100 \mathrm{~g}$ & Weight losses (\%) \\
\hline & $3 \mathrm{~g}$ & $0.70 \mathrm{bc}$ \\
Neem leaf powder & $4 \mathrm{~g}$ & $0.68 \mathrm{bc}$ \\
& $5 \mathrm{~g}$ & $0.20 \mathrm{de}$ \\
\hline & $3 \mathrm{~g}$ & $0.11 \mathrm{e}$ \\
Datura leaf powder & $4 \mathrm{~g}$ & $0.07 \mathrm{e}$ \\
& $5 \mathrm{~g}$ & $0.04 \mathrm{e}$ \\
\hline & $3 \mathrm{~g}$ & $0.80 \mathrm{~b}$ \\
Nishinda Leaf Powder & $4 \mathrm{~g}$ & $0.65 \mathrm{bc}$ \\
& $5 \mathrm{~g}$ & $0.50 \mathrm{c}$ \\
\hline & $3 \mathrm{~g}$ & $0.66 \mathrm{bc}$ \\
Garlic tablet & $4 \mathrm{~g}$ & $0.60 \mathrm{bc}$ \\
& $5 \mathrm{~g}$ & $0.47 \mathrm{~cd}$ \\
\hline Sevin 85SP & $0.25 \mathrm{~g}$ & $0.00 \mathrm{e}$ \\
Untreated check & - & $5.45 \mathrm{a}$ \\
\hline LSD & & 0.272 \\
MSE & & 0.04 \\
Level significance & & $* *$ \\
CV $(\%)$ & 15.42 \\
\hline
\end{tabular}

$* *=$ Significant at $1 \%$ level of probability, Note: Means with the same letter are not significantly different

All the botanical and chemical treatments at different rates showed significant difference in seed weight loss of maize seeds with the untreated check. Lowest seed weight loss $(0.00 \%)$ was found ar Sevin 85 SP treated seeds and highest (5.45\%) was found at control/untreated seeds (Table 1) Among the botanical treatments, lowest grain weight loss was experienced in the maize seeds treated with datura leaf powder over the 28 days exposure to the treatment at the rate of $3 \mathrm{~g}, 4 \mathrm{~g}$ and $5 \mathrm{~g}$ per $100 \mathrm{~g}$ of maize seeds while the seeds treated with nishinda leaf powder had highest seed weight loss. Datura leaf powder showed $0.11,0.07$ and $0.04 \%$ weight loss of maize seeds at the rate of $3 \mathrm{~g}, 4 \mathrm{~g}$ and $5 \mathrm{~g}$ per $100 \mathrm{~g}$ maize seeds respectively and showed significant difference with the other botanical treatments and the untreated check. However, no significant difference in seed weight loss was observed by the datura leaf powder with the chemical Sevin $85 \mathrm{SP}$. On the other hand, seed weight loss in the nishinda leaf powder treated maize seeds were $0.80,0.65$ and $0.50 \%$ at the rate of $3 \mathrm{~g}$, $4 \mathrm{~g}$ and $5 \mathrm{~g}$ per $100 \mathrm{~g}$ maize seeds respectively which showed significant difference with the seed weight loss occurred in the untreated check. Neem leaf powder showed seed weight loss of $0.70,0.68$ and $0.20 \%$ at the rate of $3 \mathrm{~g}, 4 \mathrm{~g}$ and $5 \mathrm{~g}$ per $100 \mathrm{~g}$ maize seeds respectively and showed significant difference with the seed weight loss occurred in the untreated check. seed weight loss was lower in the seeds treated with botanical and chemical treatments than the seeds which were treated with no controls can be attributed to the higher weevil mortality and lower weevil survival which resulted in lower seed damage hence lower seed weight loss. The findings are in agreement with Chiu (1989) who observed that synthetic dusts like cypermethrin $1 \%$ dust is effective in protecting stored grain thereby reducing loss of grain weight. Hall (1990) and Parwada et al. (2012) reported that ground plant extracts act by dehydrating and suffocating the weevil and also by reducing weevil movements thereby resulting in reduced grain damage and weight loss. The leaf powders of Datura stramonium, Azadirachta indica, Allium sativum L. and Vitex negundo L could also have reduced grain weight loss due to the fact that they reduce the relative humidity on the surface of the grain thereby inhibiting egg laying and larval development of the weevils. This concurs with the findings by Aslam and Suleman (1999). The findings are also in agreement with Singh et al. (1996). 


\subsection{Efect of Botanicals and Chemical on Germination of Maize Seeds}

Table 2. Effect of botanical and chemical treatments on germination of maize seeds

\begin{tabular}{|c|c|c|}
\hline Treatments & Rate $/ 100 \mathrm{~g}$ & Germination (\%) \\
\hline \multirow{3}{*}{ Neem leaf powder } & $3 g$ & 83.00 bcdef \\
\hline & $4 \mathrm{~g}$ & 84.33 bcde \\
\hline & $5 \mathrm{~g}$ & $85.00 \mathrm{abc}$ \\
\hline \multirow{3}{*}{ Datura leaf powder } & $3 g$ & $84.67 \mathrm{bcd}$ \\
\hline & $4 \mathrm{~g}$ & $85.33 \mathrm{abc}$ \\
\hline & $5 g$ & $85.67 \mathrm{ab}$ \\
\hline \multirow{3}{*}{ Nishinda Leaf Powder } & $3 g$ & $82.33 \mathrm{cdef}$ \\
\hline & $4 \mathrm{~g}$ & 83.67 bcdef \\
\hline & $5 \mathrm{~g}$ & 84.00 bcdef \\
\hline \multirow{3}{*}{ Garlic tablet } & $3 g$ & $81.33 \mathrm{ef}$ \\
\hline & $4 \mathrm{~g}$ & $81.00 \mathrm{f}$ \\
\hline & $5 g$ & $81.67 \mathrm{def}$ \\
\hline Sevin $85 \mathrm{SP}$ & $0.25 \mathrm{~g}$ & $88.00 \mathrm{a}$ \\
\hline Untreated check & - & $74.33 \mathrm{~g}$ \\
\hline LSD & & 3.19 \\
\hline MSE & & 2.00 \\
\hline Level of significance & & $* *$ \\
\hline $\mathrm{CV}(\%)$ & & 1.70 \\
\hline
\end{tabular}

** = Significant at $1 \%$ level of probability, Note: Means with the same letter are not significantly different

All the seeds treated with botanical and chemical treatments at different rates showed significant difference with seeds which were not treated with any control on germination of maize seeds. It indicated that all the botanical and chemical treatments did not adversely affect the germination of maize seeds over the 28 days exposure period to the different treatments. Highest germination (88.00\%) was found at Sevin 85SP treated seeds (Table 2). Among the botanical treatments, it was recorded that the seeds treated with datura leaf powder at the rate of $3 \mathrm{~g}, 4 \mathrm{~g}$ and $5 \mathrm{~g}$ per $100 \mathrm{~g}$ maize seeds possessed highest germination percentages. This result supports the findings of Musundire et al. (2015) stated that D. stramonium and T. minuta successfully reduced the insect infestation and showed no adverse effect on seed germination. This result also supports the findings of Fekadu et al. (2012).

\section{Conclusion}

Among the botanical treatments, datura leaf powder showed highest mortality of maize weevil, lowest weight loss of maize seeds and highest germination capacity followed by neem leaf powder. It is recommended that datura leaf powder and neem leaf powder can be effective against maize weevil when used as at $4 \mathrm{~g}$ powder/100g of maize seed. It is also economically feasible and environmentally safe. Further investigation is needed to identify the specific or actual compounds in botanical materials which are responsible for toxic action.

\section{Acknowledgement}

The author takes an opportunity to express his gratefulness to Ministry of Science and Technology for financial support to conduct research work.

Conflict of interest: no conflict of interest to report.

\section{References}

Ahad, M. A. (2003). Trinojatiyo Fashaler Balai Bebosthapana (Pest Management in Gramicious Crops) (in Bengali). Textbook Division, Bangla Academy, Dhaka, Bangladesh, pp 184.

Aslam, M., \& Suleman, M. (1999). Pest management of stored farm commodities. The Nation, 9, 5-5.

BBS. (2015). Yearbook of Agricultural Statistics of Bangladesh. Bangladesh Bureau of Statistics. Statistics and Informatics Division, Ministry of Planning, Government of the People's Republic of Bangladesh.

BBS. (2017). Yearbook of Agricultural Statistics of Bangladesh. Bangladesh Bureau of Statistics. Statistics and Informatics Division, Ministry of Planning, Government of the People's Republic of Bangladesh.

Bekele, A. J., Obeng-Ofori, D., \& Hassanali, A. (1997). Evaluation of Ocimum kenyense (Ayobangira) as source 
of repellants, toxicants and protectants in storage against three major stored product insect pests. Journal of Applied Entomology, 121, 169-173.

Chiu, S. F. (1989). Recent findings on Meliaceae and other promising botanical insecticides in Chin. Journal of Plant Insects and Disease Protection, 36, 310-319.

Cosmas, P., Christopher, G., Charles, K., Friday, K., Ronald, M., \& Belta, Z. (2012). Tagetes Minuta Formulation Effect Sitophilus zeamais (Weevils) Control in Stored Maize Grain. International Journal of Plant Research, 2(3), 65-68.

Demissie, G., Tefera, T., \& Tadesse, A. (2008). Efficacy of Silicosec, filter cake and wood ash against the maize weevil, Sitophilus zeamais Motschulsky (Coleoptera: Curculionidae) on three maize genotypes. $J$ Stored Prod Res., 44, 227-31.

Dobie, P. (1974). The susceptibility of different type of maize to post harvest infestation by Sitophilus zeamais and Sitotroga cerelella and the importance of this factor at the small scale farm level CIMMYT, 10. 98-113.

Dowswell, C. R., Paliwal, R. L., \& Cantrell, R. P. (1996). Maize in the Third World. Westview Press, Boulder, USA.

Duncan, D. B. (1951). A Significance Test for Differences Between Ranked Treatments in an Analysis of Variance. Vigrinia J. Sci., 2(9), 171-189.

Endersby, N. M., \& Morgan, W. C. (1991) Alternatives to synthetic chemical insecticides for use in crucifer crops. Biol Agri and Hort, 8(1), 33-52.

Fekadu, G., Waktole, R., \& Dante, S. (2012). Evaluation of Plant Powders and Cooking Oils against Maize Weevil, Sitophilus zeamais M. (Coleopteran: Curculionidae) under Laboratory Conditions, Molecular Entomology, 3(4), 14. https://doi.org/10.5376/me.2012.03.0002

Girma, D., Tadele, T., \& Abreham, T. (2008). Management of the maize weevil Sitophilus zeamais Motsch, (Coleoptera: Curculionidae) using Botanical insecticides on three Maize genotypes. Pest Management journal of Ethiopia, 12, 49-56.

Golob, P. (2000). A practical assessment of food losses sustained during storage by smallholder farmers in the Shire Valley Agriculture Development area of Malawi, Department of the Tropical Products Institute, Slough G 138 p- 32

Haines, C. P. (1991). Insects and Arachnids of tropical stored products: their biology and identification. A Training Manual (2nd ed), Natural Resources Institute, ISTA, India, pp. 117.

Hall, D. W. (1990). Handling and storage of food grains in the tropical and subtropical areas, FAO, Rome, Italy.

Hossain, M. S., Rahman, M. M., Rashid, M. H., Farid, A. T. M., Kaium, M. A., Ahmed, M., Alam, M. S., \& Salahuddin, K. M. (2005). Krishi Projukti Hatboi (Agricultural Technology Handbook, Part-1 in Bangla). Bangladesh Agricultural Research Institute, Joydebpur, Gazipur, Bangladesh, pp 362.

Islam, M. S., \& Shahjahan, M. (2000). Insecticidal effects of some plant extracts against rice weevil, Sitophilus zeamis L. and red flour beetle, Tribolium castaceum Herbst. Progress Agric. 11(1-2), 123-129.

Ivibijaro, M. F., Osisanya, E. O., \& Akinlade, E. E. (1979). The deterioration of commercial maize by insects and fungi. International Biodeterioration Bulletin, 15, 74-76.

Jilani, G., \& Saxena, R. C. (1990). Derivatives of neem, turmeric and sweet flag as protectant against stored grain insect pest. International Rice Res. Inst. Los Banos, Manila, Philippines. p. 186.

Maribet, L. P., \& Aurea, C. R. (2008). Insecticidal action of five plants against maize weevil, Sitophilus zeamais motsch. (Coleoptera: Curculionidae). KMITL Sci Tech J., 8(1), 24-38.

Marilei, N. S., Alberto, C. V., Augusto, T. A. P., \& Heron, O. S. L. (2010). Leaves, stems and seeds powder of neem (Azadirachta indica A. Juss.) used as repellent of Sitophilus zeamais (Coleoptera: Curculionidae) in stored corn. Brazilian Journal of Food Research, 1(1).

Masiiwa, P. (2004). Evaluation of the African diatomaceous earths as potential maize grain protectants against the maize weevil (Sitophilus zeamais). University of Zimbabwe. Harare.

Mulungu, L. S., Lupenza, G., Reuben, S. O. W. M., \& Misangu, R. N. (2007). Evaluation of Botanical Products as Stored Grain Protectant Against Maize Weevil, Sitophilus zeamays (L.) on Maize. Journal of Entomology, 4, 258-262. 
Musundire, R., Mazodze, F., Macheka, L., Ngadze, R. T., Mubaiwa, J., \& Manditsera, F. (2015). Eucalyptus grandis and Tagetes minuta leaf powders effectively protect stored maize against Sitophilus zeamais without affecting grain organoleptic properties. African Journal of Agricultural Research, 10(2), 49-57.

Nazli, R., Jilani, G., Ibrahim, F., Kazmi, A. R., \& Solangi, A. H. (2008). Repellency of garlic oil obtained from different localities of Pakistan against red flour beetle, Tribolium castaneum (Herbst). Pakistan. Entomol. 26(23), 206-2010.

Nukenine, E. K., Goudoungou, J. W., \& Adler, C. Reichmuth. (2010). Efficacy of diatomaceous earth and botanical powders against the maize weevil, Sitophilus zeamais Motschulsky (Coleoptera: Curculionidae) on maize, 10th International Working Conference on Stored Product Protection. https://doi.org/10.5073/jka.2010.425.176

Park, I. K., Lee, S. G., Choi, D. H., Park, J. D., \& Anh, Y. J. (2003). Insecticidal activities of constituents identified in the essential oil from leaves of Chamaecyparis obtuse against Callosobruchus chinensis (L.) and Sitophilus zeamis (L.). J Stored Prod. Res., 39, 375-384.

Parwada, C., Gadzirayi, C., Karavina, C., Kubiku, F., Mandumbu, R., \& Madumbu, B. Z. (2012). Tagetes minuta formulation effect Sitophilus zeamais (weevils) control in stored maize grain, International Journal of Plant Research, 2(3), 65-68. https://doi.org/10.5923/j.plant.20120203.04

Purseglove, J. W. (1975). Tropical crops:Monocotyledons. USA: Longman Group Limited, 551 pp.

Rajendran, S., \& Sriranjini, V. (2008). Plant products as fumigants for stored-product insect control. J. Stored Prod. Res., 44, 126-135.

Shaw, R. H. (1988). Climate requirement. In: Sprague G.F., Dudly J.W eds. Corn and Corn 638 Improvement, 3rd ed Madism, WI:ASA 609.

Shiberu, T., \& Negeri, M. (2017). Determination of the appropriate doses of promising botanical powders against maize weevil, Sitophilus zeamais Mots. (Coleoptera: Curculionidae) on maize grain. Journal of Stored Products and Postharvest Research, 8(4), 49-53. https://doi.org/10.5897/JSPPR2014.0177.

Singh, H., Mrig, K. K., \& Mahla, J. C. (1996). Efficacy and persistence of plant products against lesser grain borer, Rhizopertha dominica in wheat grain. Ann. Biol. Ludhiana, 12(1), 99-103.

Talukder, F. A., \& Howse, P. E. (1995). Evaluation of Aphanamaxis polystachya as a source of repellents, antifeedants, toxicants and protectants in storage against Tribolium castaneum (Herbst). Journal of Stored Product Research, 31, 55-61.

Throne, J. E. (1994). Life history of immature maize weevils (Coleoptera: Curculionidae) on corn stored at constant temperatures and relative humidities in the laboratory, Environmental Entomology, 23, 1459-1471.

Udo, I. O. (2005). Evaluation of the potential of some local spices as stored grain protectants against the maize weevil, Sitophilus zeamais Motsch (Coleoptera: Curculionidae). Journal of Applied Sciences and Environmental Management, 9(1), 165-168.

Zaidi, G., \& Singh, S. K. F. (2005). Morphology and growth of maize-IITA/ CIMMYT Research, Guide 12, IITA. Ibadan, Nigeria, pp. 15-18.

\section{Copyrights}

Copyright for this article is retained by the author(s), with first publication rights granted to the journal.

This is an open-access article distributed under the terms and conditions of the Creative Commons Attribution license (http://creativecommons.org/licenses/by/4.0/). 